\title{
KAJIAN EPISTEMOLOGIS ILMU USSŪL AL-FIQH Studi terhadap Pemikiran Abū Isḥāq Ibrāhīm al-Shīrazī al-Fayrūz Abādī
}

\author{
Amir Tajrid \\ IAIN Samarinda \\ e-mail: tajrid2150@gmail.com
}

\begin{abstract}
This article intends to conduct epistemological critique of the the Book "al-Luma" that written by Abū Ibrāhīm al-Shīrazī Ishāq al-Fayrūz Abādī (al-Shīrazī). This paper, trying to explore and criticize the characteristics and knowledge of usūl al-fiqh that contained in. There are some important notes: first the thinking of al-Shīrazi on usūl al-fiqh is written in the golden era of usūl al-fiqh works, that makes the methods and subjects of thought of al-Shïrazī on ușūl al-fiqh became inspiration for the next generation. Study of content of usūl al-fiqh is based on the its method of predecessor leaders. This is proved by the dominance of the comparative method which is used when explores usūl al-figh of several different leaders view. Second, al-Shīrazī included as experts of usūl, which has original thinking and independent. A sharp criticism launched, invite the parties to be impartial towards certain schools of thought. Therefore the presentation of ideas alShîrazī on usūl al-figh is in the sense of kalämī, because the arguments are built from elements of kaläm and prioritize the logic as a tool in assessing and measuring the truth of usuul al-fiqh. Third, al-Luma has fulfilled the basics of science both in ontology, epistemology, and axiology.
\end{abstract}

[

Artikel ini bermaksud melakukan kritik epistemologis terhadap Kitab al-Luma' yang ditulis oleh Abū Ishāq Ibrāhīm al-Shīrazī al-Fayrūz Abādī (al-Shīraz̄ī). Tulisan ini, secara deskriptif berusaha menggali dan mengkritisi karakteristik dan pengetahuan mengenai ilmu ușūl al-fiqh yang terkandung di dalamnya. Beberapa catatan penting terhadap kitab ini adalah: pertama, pemikiran ușūl al-fiqh al-Shīrazī dalam Kitab al-Luma' ditulis pada era keemasan karya-karya usūl al-fiqh, sehingga metode dan pokok-pokok pemikiran ușūl al-fiqh al-Shīrazī menjadi inspirator generasi berikutnya. Kajian materi ușūl al-fiqh didasarkan pada metode para tokoh pendahulunya, terbukti pada dominasi metode komparatif yang digunakan ketika mengetengahkan materi ușūl al-fiqh dari beberapa tokoh ușūl al-figh yang berbeda pandangan. Kedua, al-Shīrazī termasuk dalam barisan ahli ushul mutakallimin yang mempunyai pemikiran orisinil dan merdeka. Kritik tajam yang dilancarkan mengajak para pihak untuk tidak condong terhadap mazhab fikih tertentu. Oleh karena itu penyajian pemikiran ușūl al-fiqh al-Shïrazì dalam al-Luma'lebih bersifat kalamī, karena bangunan argumentasi yang melibatkan unsur-unsur kalam dan mengedepankan logika menjadi alat dalam menilai dan mengukur kebenaran ilmu ușūl al-fiqh. Ketiga, al-Luma' telah memenuhi dasar-dasar ilmu pengetahuan baik secara ontologi, epistemologi, maupun aksiologi.

Keywords: ușūl al-fiqh, al-Luma', epistemologi, al-Shīrazī

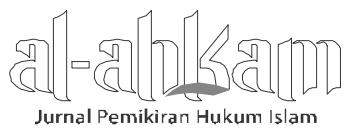

Volume 22, Nomor 2, Oktober 2012 


\section{Pendahluan}

Secara historis, cikal bakal pemikiran ușūl al-fiqh sesungguhnya telah ada sejak masa Rasulullah SAW. Satu peristiwa memperkuat fakta historis tersebut yaitu ketika Rasulullah SAW ditanya 'Umar ibn al-Khatțāb RA. ${ }^{1}$ dan sahabat Jabir RA. ${ }^{2}$ setelah mencium isterinya di siang hari bulan Ramadhan. Keduanya bertanya kepada Rasulullah SAW perihal kejadian (mencium isteri di siang hari bulan Ramadhan) yang telah mereka lakukan. Batal atau tidakkah puasanya? Rasulullah SAW menjawab dengan meng-qiyās-kan peristiwa tersebut kepada seseorang yang berkumur ketika sedang berpuasa. Rasulullah SAW tidak membatalkan puasa kedua sahabat tersebut.

Menurut 'Abdul Wahhāb Khallāf, pemikiran ușūl al-fiqh ketika dilihat sebagai pemikiran yang dituangkan dalam bentuk karya tertulis, maka dapat dibagi ke dalam tiga fase, yaitu: fase awal, fase perkembangan, dan fase kesempurnaan. ${ }^{3}$ Tiga fase tersebut pada gilirannya melahirkan banyak tokoh pemikir ușūl al-fiqh. Salah

1Peristiwa yang dialami sahabat Umar ibn al-Khaththab ra. terdokumentasi dalam sebuah hadis yang di riwayatkan oleh Imam Ahmad dan Abu Dawud, sebagai berikut:

$$
\begin{aligned}
& \text { ويدل لذالك ما أخرجه أحمد وابو داود من حديث عمرابن الخطاب قال هششت يوما فقبلت وانا } \\
& \text { صائم فأتيت النبي صلى الله عليه وسلم فقلت صنعت اليوم امرا عظيما فقبلت وانا صائم فقال } \\
& \text { رسول الله صلى الله عليه وسلم ارئيت لو تمضمضت بماء وانت صائم قلت لابأس بذالك فقال } \\
& \text { رسول الله صلى الله عليه وسلم ففيم؟! إنتهى. }
\end{aligned}
$$

Muhammad ibn Ismāîl al-Amirī al-Șan'ānī, hadis ini dinilai sebagai hadis șaḥịh. Selengkapnya lihat Muhammad ibn Ismāîl al-Amirī al-Ṣan'ānī; Muḥammad Subḥī Ḥasan Hallāq (ed)., Subul al-Salām, Cet. II, Jilid IV (Riyāḍ: Dār Ibn al-Jawzī, 1421 H).

2Menyangkut peristiwa sahabat Jabir ra., al-Shīrazī, telah membahasanya dalam karyanya, alMuhadhdhab pada bab tentang puasa dengan menyebutkan hadis yang diriwayatkan oleh sahabat tersebut. Redaksinya:

$$
\text { أرئيت لو روى جابر قبلت وأنا صائم ثثمم أتيت النبي صلى الله عليه وسلم فقلت قبلت وأنا صائم فقال }
$$

Selengkapnya lihat Abū Ishāq Ibrāhīm al-Shīraz̄ al-Fayrūz Abādī, al-Muhadhdhab fí Fiqh al-Imām al-Shafi'î, juz I, Cet. I (Beirut-Lebanon: Dār al-Kutub al-'Ilmiyyah), 1995, h. 335.

${ }^{3}$ Abdul Wahhāb Ibrahim ibn Sulayman, al-Fikr al-Ușūlī: Dirāsah Taḥlīliyyah Naqdiyyah, (t.tp.: t.p., t.th.), h. 96-165. 
satu tokoh uṣūl al-fiqh yang pemikirannya belum banyak dikaji adalah Abū Ishāà Ibrāhīm al-Shīrazī al-Fayrūz Abādī (al-Shīrazī) yang menulis Kitab al-Luma' fi Ușūl al-Fiqh dan al-Tabșirah.

Mengangkat dan mempublikasikan karya dan pemikiran para tokoh uṣūl alfiqh merupakan bagian dari riset akademik sebagai upaya peningkatan wawasan dan pengetahuan mengenai ilmu ușūl al-fiqh yang masih banyak belum tergali. Atas dasar itu, tulisan ini berusaha mengungkapkan pemikiran uṣūl al-fiqh al-Shīrazī dan karakteristiknya dalam kitab al-Luma' fi Ușūl al-Fiqh.

\section{Biografi al-Shīrazī}

Abū Ishạq Ibrāhīm al-Shīrazī al-Fayrūz Abādī menurut al-Sam’ānī sebagaimana yang dikutip Ibn Khallikan dalam kitab al-Dzayl, sering di juluki "Jamaluddin." Ia lahir pada tahun 393 H di Fairuzzabad, sebuah desa di Fāris dan sana pula ia dibesarkan Ia wafat pada malam Ahad tanggal 21 Jumadil Akhir atau Jumadil Ula pada tahun $476 \mathrm{H}$ di Baghdad dan disemayamkan di suatu tempat yang bernama Bab Abraz. ${ }^{4}$ Pada tahun $410 \mathrm{H}$, ia masuk di Shīrāz dan belajar fikih pada beberapa ulama besar, seperti Abū Aḥmad Abdul Wahhāb ibn Muḥammad ibn Amīn, Abū Abdullāh Muhammad ibn 'Abdullāh al-Baiḍāwī, dan Abū al-Qāsim ibn 'Umar al-Karḥī. Lalu, ia menetap di Bashrah dan berguru pada al-Khūzī, berpindah di Baghdad pada bulan Shawwal tahun 415 H dan berguru pada Qāḍi Abū al-Ṭayyi al-Ṭabarī dalam waktu yang cukup lama dan ia pun dipercaya untuk menggantikan kedudukannya serta menjadi asisten di halaqah-nya. Dengan keahlian dan penguasaan ilmu pengetahuan yang dimilikinya, ia dipercaya menjadi imam di Baghdad. 5

Ketika Wazir Nizām al-Mulk mendirikan universitas di Baghdad, di awal pembukaannya, ia diminta menjadi dosen sekaligus rektor, tetapi permintaan tersebut tidak dijalankannya. Kemudian jabatan tersebut dipercayakan kepada Abū Nașr ibn Șabbāgh, ${ }^{6}$ penulis kitab "al-Shāmil" dalam kurun waktu 20 hari. Kemudian

\footnotetext{
${ }^{4}$ Ibn Khallikan, Wafāyāt al-A'yān wa Anbā’u Abnāi' 'al-Zamān, Dr.Ihsan Abbas (ed.), Jilid I, (BeirutLebanon: Dār al-Tsaqāfah, 1970), h. 30.

${ }^{5}$ Ibid. h. 29.

${ }^{6}$ Nama lengkapnya Abū Nașr 'Abd 's-Sayyid ibn Muhammad ibn 'Abd al-Wāhid ibn Ahmad ibn Ja'far dan terkenal dengan sebutan "Ibn al-Ṣabbāgh", ahli hukum bermadzhab Syafi'i dan ahli hukum Irak di masanya. Ia mempunyai banyak kemiripan dengan Abū Ishāa al-Shīrāzī dan lebih dulu mengenal madzhab Syafíi dari pada al-Shīrāzì. Selengkapnya simak Ibn Khallikan, Wafāyāt al-A'yān wa Anbā’u Abnā’ial-Zamān, h. 217.
} 
jabatan tersebut diserahkan kembali kepada Abū Isḥāq Ibrāhīm al-Shīrāzī setelah ia menerima tawaran dari Wazīr Nizāàm al-Mulk hingga akhir hayatnya. Setelah itu jabatan rektor diserahkan kembali kepada Abū Nașr ibn al-Ṣabbāgh kembali.7 Menurut penuturan Ibn Najjār dalam Tārīkh Baghdād, ketika al-Shīrāzī wafat, urusan tata kelola universitas Niḍāmiyah dipegang oleh Abū Sa'ad al-Mutawally, kemudian pada tahun $476 \mathrm{H}$ dihentikan dan dikembalikan lagi ke tangan Abū Nașr ibn al-Ṣabbāgh. ${ }^{8}$

al-Shīrāzī berguru hadis kepada Abū Bakar Aḥmad ibn Muhammad ibn Aḥmad ibn Ghālib al-Khawārizmī al-Barqānī al-Ḥāfiẓ, Abū 'Alī al-Ḥasan ibn Aḥmad ibn Ibrāhīm ibn Shadhān al-Bazzār, Abū al-Farrāj Muḥammad ibn 'Abdullāh alKharjūshī al-Shīrāzī, dan lainnya. Di bidang karya imiah, beliau tergolong ulama produktif, di antara karyanya adalah al-Muhadhdhab fi 'l-Mazhab, al-Tanbīh (keduanya dalam bidang fikih), al-Luma' dan sharah-nya dalam bidang ușūl al-fiqh, al-Nukāt yang mengulas tentang perbedaan (khilāf), al-Tabșirah, al-Ma'ūnah, alTalkhīs (ketiganya mengulas tentang seni berdebat (jidāl). Selain itu, ia termasuk penyair genius dan sya'ir-sya'ir indahnya dapat dilihat dalam kitab-kitab sejarah. ${ }^{9}$

\section{Metode Penulisan Kitab al-Luma'}

Kitab al-Luma' fì Ușūl al-Fiqh karya al-Shīrāzī ditulis pada abad ke-5 H, masa kejayaan penulisan kutub al-turāth. Latar belakang penulisan bermula dari permintaan sebagian kawan-kawannya untuk menulis ringkasan dalam bidang ușūl al-fiqh mazhab Imām al-Syafi'i untuk dikombinasikan dengan kitab al-Tabșirah yang menjelaskan mengenai perbedaan di kalangan para pakar uṣūl al-fiqh. Penunjukan perbedaan-perbedaan yang ada di kalangan ulama ușūl al-fiqh ini di lakukan dengan menyertakan argumentasi (dalīl) yang melandasinya. Atas permintaan dan memenuhi tuntutan kebutuhan masyarakat kemudian ditulislah kitab tersebut.10

\footnotetext{
${ }^{7}$ Abū al-Ḥasan Muhammad ibn Hilāl ibn al-Ṣābi' menuturkan bahwa universitas Niẓāmiyyah pertama kali dibangun pada bulan Dzulhijjah tahun 457 H dan dibuka pertama kali pada hari Sabtu tanggal 10 Dhulqa'dah tahun $459 \mathrm{H}$. Dilihat dari tahun pendirian dan pembukaannya, universitas ini dibangun memakan waktu 2 tahun. Lihat Ibn Khallikan, Wafāyāt al-A'yān..., h. 218.

8 Ibid.

9Ibid,, h. 29-30.

${ }^{10}$ Lihat Abū Ishāāq Ibrāhīm al-Shīrazī, al-Luma'(Semarang: Penerbit Karya Thoha Putra, t.th.), h. 2. 
Berdasarkan penulusuran penulis, kajian terhadap kitab al-Luma' dapat dilaporkan sebagai berikut, yaitu: pertama, secara akademis kitab al-Luma' secara original adalah karya al-Shīrāzī, karena itu tidak diperlukan editing terhadap karya tersebut. Penegasan ini berguna untuk menilai tingkat independensi dan keilmiahan dengan melihat materi serta ada-tidaknya pemikiran tokoh-tokoh ușūl alfiqh lain yang dijadikan rujukan. Kedua, metode penulisannnya dilakukan dengan mengetengahkan ragam perbedaan pandangan tentang topik yang dibicarakan di kalangan ulama ușūl al-fiqh dan dalil-dalil yang mendukungnya, lalu beliau menjelaskan pandangannya dengan dukungan argumentasi yang dibangun sendiri. ${ }^{11}$ Ketiga, al-Shīrāzī dikenal sebagai sosok pengikut aliran uṣūl al-fiqh mutakallilmin, terbukti sebelum menjelaskan materi-materi ușūl al-fiqh terlebih dahulu ia menjelaskan tentang ta'rīf (definisi) masalah yang akan disajikan, 'ilm, zann, shakk, wahm, jahl, dan hal lain terkait dengannya. Ia juga menjelaskan pengertian nazar dan dalīl, dilanjutkan dengan penjelasan tentang fiqh dan ușūl al-fiqh. Metode demikian ini menurutnya lebih dapat mengantarkan seseorang pada pemahaman yang baik terhadap fikih, sementara nazar dan dalì akan mengantarkan seseorang pada pemahaman mengenai 'ilm dan zann.12

\section{Topik-topik Inti Kitab al-Luma'}

Sebelum menjelaskan topik-topik utama ușūl al-fiqh, beliau menjelaskan terlebih dahulu ta'rif dan maksud ilmu fiqh dan ilmu ușūl al-fiqh serta materimaterinya. Penjelasan umum ini berguna bagi para pengkaji pemula ilmu ușūl alfiqh dalam memberikan gambaran awal mengenai bentuk, sosok, serta cakupan permasalahnnya. ${ }^{13}$ Ilmu fikih menurutnya adalah ilmu untuk mengetahui hukumhukum syara' dengan melalui metode ijtihād. Norma hukum-hukum syara' dapat berupa wājib, mandūb, mubāh, mahẓūr, makrūh, șaḥihh, dan bāțil. Sementara ilmu uṣūl al-fiqh adalah dalil-dalil ('adillah) ${ }^{14}$ hukum yang menjadi dasar bagi fikih dan metode-metode yang dapat menyampaikan seorang mujtahid pada dalil-dalil hukum tersebut secara global (ijmālì).

\footnotetext{
11 Ibid.

12Ibid, h. 2-3.

${ }^{13}$ Ibid. h. 2.

${ }^{14}$ 'Adillah mencakup perkataan/firman (khițāb) Allah SWT dan sabda, perbuatan, dan ketetapan Nabi Muhammad SAW, kesepakatan umat, qiyas, penetapan hukum asal ketika tidak ditemukan dalil-dalil yang telah disebutkan tadi, dan fatwa seorang yang alim bagi orang kebanyakan (awam).
}

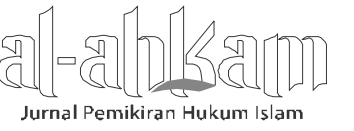


Adapun topik utama yang terkandung dalam kitab tersebut adalah: Pertama, mengenai firman (khițāb) Allah SWT dan sabda Nabi Muhammad SAW. Keduanya merupakan dasar bagi dalil-dalil hukum lainnya. Pembahasan mengenai khitāb ini mencakup beberapa bab yang mengulas tentang aqsām al-kalām, haqīqāt dan majāz, bayān al-wujūh allatī tu'khadh minha I-asmā' wa I-lughāt, amr dan nahy, umum dan khusus, mujmal dan mubayyan, mafhūm, mu'awwal, dan nāsikh-mansūkh. Kedua, mengenai perbuatan/perilaku dan ketetapan Nabi Muhammad SAW. Tema ini menjadi topik utama dalam kitab ini karena menurutnya, perilaku dan ketetapan Nabi Muhammad SAW dapat berjalan menempati posisi ucapan-Nya dalam konteks al-bayān. Ketiga, mengenai akhbār (jamak dari khabar), cerita-cerita yang disandarkan kepada Nabi Muhammad SAW. Menurut al-Shīrāzī, pengetahuan yang memadai tentang khabar akan mengantarkan seseorang mengetahui ucapan dan perbuatan Nabi Muhammad SAW dengan baik.

Keempat, pembahasan mengenai ijma'. Ijma' dapat ditetapkan sebagai dalil hukum dengan dua hal, yaitu: al-Qur'an dan Hadis Nabi Muhammad SAW, dan berdasarkan al-Qur'an dan Hadis pula ijma' dapat terjadi. Kelima, mengenai qiyās. Qiyās dapat ditetapkan sebagai dalil hukum dengan dalil-dalil yang telah disebutkan dan kepada dalil-dalil tersebut qiyās bersandar kepadanya. Keenam, mengenai istihsan. Ketujuh, mengenai hukum asal sesuatu. Ini dipandang sangat urgen karena ketika dalil-dalil suatu kasus tertentu tidak ditemukan, maka seorang mujtahid akan bergegas kepada hukum asalnya; Kedelapan, mengenai tata urutan penggunaan dalil dan proses pengeluarannya; Kesembilan, mengenai taqlìd, termasuk apa yang membolehkan dan yang melarangnya serta siapa yang dibolehkan dan dilarang bertaqlid. Kesepuluh, mengenai fatwa, orang yang memberi fatwa ( $m u f t i)$, orang yang meminta fatwa (mustafti) dan syarat-syaratnya. Fatwa dapat menjadi metode bagi penetapan hukum setelah mengetahui dan memahami topik-topik utama yang telah disebutkan. Kesebelas, mengenai ijtihād dan hal-hal yang terkait dengannya. ${ }^{15}$

\section{Pokok-pokok Pikiran Uṣūl al-Fiqh al-Shīrāzī}

Pembahasan mengenai topik utama kitab al-Luma', hampir seluruhnya merupakan pemikiran murni al-Shīrāzī. Penilaian ini diketengahkan, khususnya ketika al-Shīrāzī membahas topik tertentu yang berasal dari pendapat ulama ușūl al-fiqh lain, beliau menyebutkan nama atau faham/kelompok ulama ușūl al-fiqh tersebut. Ini berarti ketika ia tidak menyebutkan nama tokoh lain dapat diyakini sebagai

\footnotetext{
${ }^{15}$ Ibid.
}

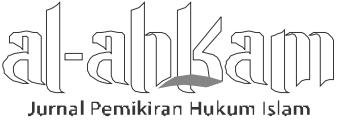


pemikiran pribadinya. Sebagai contoh ketika al-Shīrāzī membahas tentang istihsān, ia menyebut nama Abu Hanifah, pencetus teori istihsan dan memberikan definisi istihsān sesuai dengan definisi yang telah diberikan Abu Hanifah, baru menyebutkan definisi istihsān ulama lainnya.

\section{Khitäb Allah}

Al-Luma' sebagai karya monumental al-Shīrāzī juga mengulas tentang konsepkonsep atau pengertian-pengertian untuk memahami makna atau pesan dari sebuah kalam, seperti: aqsām al-kalām, haqīqāt dan majāz, bayān al-wujūh allatī tu'khadh minha I-asmā' wa I-lughāt, amr dan nahy, umum dan khusus, mujmal dan mubayyan, mafhūm, mu'awwal, dan nāsikh-mansūkh. Untuk merefleksikan bagaimana pemikiran al-Shīrāzī terkait dengan pembahasan mengenai khițāb Allah SWT dan Nabi-Nya, dapat diambil dari konsepnya tentang dimensi-dimensi pengambilan nama dan bahasa (al-wujūh allatī tu'khadh minha I-asmā' wa 'l-lughāt). Menurut al-Shīrāzī, nama dan bahasa dapat diambil dari empat dimensi, yaitu: bahasa (al-lughāt), adat/ kebiasaan yang hidup dalam masyarakat ('urf), shara', dan analogi (qiyās). ${ }^{16}$

Bahasa yang digunakan sebagai alat komunikasi bangsa Arab terbagi menjadi dua, yaitu: 1) hanya menjelaskan satu makna/maksud/pesan saja, seperti: kata alrajul (seorang laki-laki), al-faras (seekor kuda), al-tamr (kurma), al-burr (gandum), dan lainnya; 2) menjelaskan banyak makna. Ini terbagi menjadi dua: (a) menjelaskan makna yang sama (ma'ānī muttafiqah), seperti kata al-lawn yang berarti warna, di mana kata warna ini meliputi warna putih, hitam, hijau, dan warna-warna lainnya; kata al-musyrik yang meliputi Yahudi dan Nasrani; (b) menjelaskan makna yang berbeda (ma'anī mukhtalifah), seperti kata al-bidah, yang dapat berarti seorang wanita muda/gadis, telor ayam, telor burung unta; kata al-qur' yang berarti haidh dan suci. Terkait dengan kata yang bermakna banyak ini pengikut Abu Hanifah dan sebagian pengikut Mu'tazilah tidak membolehkan pemuatan dua makna yang berbeda dari sebuah kata. Namun pandangan tersebut ditentang oleh al-Shīrāzī. Menurutya pembolehan pemuatan dua makna yang berbeda dari sebuah kata didasarkan pada argumentasi bahwa tidak ada pertentangan diantara dua makna. ${ }^{17}$

'Urf, yang di maksud di sini adalah makna/pemahaman yang berlaku umum di masyarakat bukan makna/pemahaman yang diletakkan oleh bahasa. Seandainya

\footnotetext{
${ }^{16}$ Ibid.h. 5 .

${ }^{17}$ Ibid. h. 5-6.

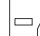

Jurnal Pemikiran Hukum Islam
} 
suatu kata diucapkan, maka makna/pemahaman yang berasal dari kata tersebut dapat dipahami dengan cepat dari makna/pemahaman yang umum berlaku di masyarakat bukan makna/pemahaman yang diletakkan oleh bahasa. Misalnya, kata dabbah, yang semula kata diperuntukkan bagi setiap binatang yang melata di atas bumi, tetapi kemudian berlaku secara umum bagi seekor kuda (al-faras). Demikian juga kata gha'it. Ssemula kata ini diperuntukkan bagi tempat yang tenang di muka bumi, tetapi kemudian berlaku secara umum bagi sesuatu (kotoran) yang keluar dari manusia. Berdasarkan penjelasan ini, makna yang umum berlaku di masyarakat menjadi makna hakiki dan ketika sebuah kata diucapkan, maka kata tersebut memuat makna yang telah ditetapkan oleh 'urf. ${ }^{18}$

Istilah shara' yang di maksud di sini adalah makna/pemahaman yang lazim menurut shara' bukan makna/pemahaman yang diletakkan oleh bahasa. Ketika suatu kata diucapkan, maka tidak dapat dipahami kecuali makna/pemahaman berdasarkan shara'. Contohnya kata șalāt yang berarti nama bagi sesuatu do'a. Kemudian secara shara' hal tersebut dijadikan nama bagi sesuatu yang sudah umum dikenal tersebut.19

Sebagian Syafi'iyah yang bermazhab Asy'ariyah berpendapat bahwa tidak ada suatu pun makna yang dapat dipindahkan ke dalam pengertian shara'. Maknamakna tersebut secara keseluruhan tetap berada pada tempatnya masing-masing secara kebahasaan. Misalnya, șalāt adalah nama bagi sebuah do'a. Sementara rukü' dan sujūd merupakan perbuatan tambahan yang disandarkan kepada șalāt, dimana keduanya bukanlah bagian dari șalāt. Sebagaimana disandarkannya țaharah kepada șalāt, di mana ia bukanlah bagian dari șalāt. Al-Shīrāzī, lebih cenderung membenarkan pendapat yang pertama, yaitu ada makna yang dapat dipindahkan ke dalam pengertian shara'. Ia mendalilkan bahwa bila kata-kata tersebut diucapkan menurut pengertian shara', maka tertutuplah makna/pemahaman yang diletakkan secara bahasa. Ini sudah cukup membuktikan adanya perpindahan makna (pemahaman) ke dalam pengertian shara' ${ }^{20}$

Apabila terjadi benturan di antara makna lughāt, 'urf, dan shara', maka makna 'urf yang harus didahulukan karena makna 'urf yang datang dan menghampiri makna bahasa (lughāt). Hukum yang timbul akibat makna 'urf harus diberlakukan.

\footnotetext{
${ }^{18}$ Ibid. h. 6.

${ }^{19}$ Ibid.

${ }^{20}$ Ibid.
} 
Apabila terjadi benturan antara makna bahasa dengan makna shara', maka makna shara' yang harus didahulukan karena makna shara' yang datang menghampiri makna bahasa. Di samping karena tujuan yang dimaksud adalah menjelaskan hukum shara', maka pemuatan makna shara' sekaligus hukum yang ditimbulkan tentu lebih utama. ${ }^{21}$

Qiyās dipahami seperti penamaan sodomi (liwāt) dengan zina karena dianalogikan terhadap persenggamaan perempuan (waț'un 'ala 'l-nisā'), penamaan nabìdh dengan khamr karena dianalogikan (qiyāsan) terhadap perasan anggur ('athīr al-'inab). Menurut al-Shīrāzī, masyarakat Arab menyebut benda-benda pada masanya dengan nama-nama tertentu walaupun kemudian benda-benda tersebut musnah karena mereka musnahkan sendiri. Secara realitas, masyarakat telah bersepakat terhadap penamaan benda-benda sejenis dengan nama-nama tersebut. Hal ini menunjukkan bahwa mereka telah menganalogkan benda-benda sejenis terhadap benda-benda yang telah mereka namakan. ${ }^{22}$

\section{Perilaku Nabi}

Al-Shīrāzī menjelaskan bahwa perbuatan Nabi Muhammad SAW, terbagi menjadi dua, yaitu: perbuatan yang bernilai ibadah dan yang tidak bernilai ibadah. Bila perbuatan tersebut tidak bernilai ibadah seperti: makan, minum, berpakaian, berdiri, dan duduk, maka perbuatan tersebut menunjukkan kebolehan (ibāhaha) karena tidak menetapkan ke-haram-an. Perbuatan yang bernilai ibadah dirinci menjadi tiga hal: 1) perbuatan Nabi Muhammad SAW yang berfungsi menjelaskan bagi perbuatan-Nya yang lain; 2) perbuatan Nabi Muhammad SAW yang berupa tuntutan/perintah (amr) syara'; 3) perbuatan Nabi Muhammad SAW yang dilakukan tanpa sebab dan Nabi Muhammad SAW lah yang melakukannya pertama kali. Dalam hal ini ulama ușūl al-fiqh (așhābunā) terbagi dalam tiga pendapat: a) perbuatan Nabi SAW tersebut dikategorikan wajib kecuali ada dalil yang menunjukkan lain; b) dikategorikan sunah kecuali ada dalil yang menunjukkan wajib; c) tawaqquf, tidak dikategorikan wajib atau pun sunah kecuali ada dalil yang menunjukkannya. Ini pendapat Abu Bakar al-Șairafi dan inilah pendapat yang paling benar menurut al-Shīrāzī. ${ }^{23}$

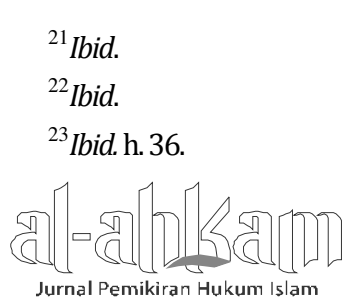


Perbuatan Nabi yang telah diketahui bahwa ia melakukannya atas dasar wajib atau sunah, maka perbuatan tersebut merupakan syariat bagi umat kecuali ada dalil yang menunjukkan bahwa perbuatan tersebut merupakan kekhususan bagi Nabi. ${ }^{24}$ Perbuatan Nabi berimplikasi kepada aneka macam bayān (anwa' al-bayan), seperti bayān al-mujmal, takhșiș al-umūm, ta'wīl al-zahīr, dan nasakh. Contoh bayān al-muj$m \bar{a} l$ adalah perbuatan Nabi terkait dengan shalat dan haji, dimana dalam perbuatan tersebut terdapat penjelasan sesuatu yang masih global yang ada dalam al-Qur'an. Contoh takhșiș al-'umūm, adalah bahwa Nabi melarang shalat setelah waktu așar sampai dengan tenggelamnya matahari. Hadis lain meriwayatkan bahwa Nabi melakukan shalat yang mempunyai sebab setelah menjalankan shalat Ashar. Di dalam contoh ini terdapat pengkhususan/ pengecualian umumnya larangan (takhșiș al-'umūm al-nahyi). Contoh ta'wìl al-zahïr yaitu seperti hadis yang meriwayatkan larangan pemotongan anggota badan (qișaș) sebelum sembuh. Dalam konteks ini diketahui bahwa maksud larangan Nabi tersebut adalah karāhiyyah (anjuran peninggalan) bukan tahrīm (perintah peninggalan). Adapun contoh nasakh, seperti hadis Nabi yang menyatakan bahwa hukuman pezina laki-laki dan perempuan yang belum pernah menikah adalah dijilid seratus kali dan dibuang selama satu tahun sedangkan hukuman pezina laki-laki dan perempun yang sudah menikah adalah dijilid seratus kali dan dirajam (dilempari batu hingga mati). Kemudian setelah itu diriwayatkan bahwa Nabi merajam Ma'iz tetapi tidak menjilidnya. Hal ini menunjukkan bahwa hadis yang pertama di-nasakh oleh hadis yang kedua. 25

Menurut al-Shīrāzī, bila ucapan dan perbuatan bertetangan di dalam al-bayān, maka menurut Syafi'iyah ada beberapa pandangan: 1) ucapan lebih utama; 2) perbuatan lebih utama; dan 3) ucapan dan perbuatan mempunyai posisi yang sama. al-Shīrāzī mendukung pendapat yang pertama karena dasar al-bayān adalah ucapan dan bahwa ucapan (qawl) dengan sighat-nya itu cakupannya dapat diperluas sementara perbuatan (fi'i) tidak dapat diperluas kecuali dalil yang mendukungnya. Karena itu, ucapan lebih utama dari pada perbutan. ${ }^{26}$

Adapun tentang penetapan Nabi Muhammad SAW, menurut al-Shīrāzī, adalah bila Nabi Muhammad SAW mendengarkan sesuatu, maka beliau tidak memungkirinya atau beliau melihat suatu perbuatan, maka beliau tidak memungkirinya selama

\footnotetext{
${ }^{24}$ Ibid.

${ }^{25}$ Ibid. h. 37.

${ }^{26}$ Ibid.
} 
tidak ada perkara yang menghalanginya. ${ }^{27}$ Perbuatan yang dilakukan di masa Nabi dan beliau tidak memungkirinya, maka dapat diklasifikasikan sebagai berikut: 1) Perbuatan tersebut termasuk bagian yang tidak boleh tersamarkan dari Nabi dari sisi kebiasaan (min tarīq al-'âdah), maka posisinya menempati apa yang dilihatnya dan beliau tidak memungkirinya. Hal ini seperti hadis yang meriwayatkan bahwa Mu'ādh shalat Isya' bersama Nabi, lalu ia mendatangi kaumnya di Bani Salamah dan shalat lagi bersama mereka. Shalat Isya' bagi Mu'ādh adalah sunnah sementara bagi mereka adalah wajib. Fakta ini menunjukkan kebolehan melakukan shalat fardhu di belakang shalat sunnah. Andaikan perbuatan ini terlarang, tentu Nabi melarangnya; 2) Perbuatan tersebut termasuk yang boleh tersamarkan dari Nabi. Hal ini seperti yang diriwayatkan dari sebagian kaum Anshar yang mengatakan bahwa: "Kami menggauli isteri pada masa Nabi, kami merasa malas dan tidak mandi," maka perbuatan tersebut tidak menunjukkan adanya hukum karena dilakukan secara rahasia dan Nabi dibolehkan tidak mengetahuinya sementara mereka tidak mandi. Karena pada dasarnya tidak ada kewajiban mandi, karena itu pula hal ini tidak bisa dijadikan hujjah dalam menggugurkan kewajiban mandi.28

Adapun diamnya Nabi mengenai hukum sesuatu ketika melihat seseorang melakukan perbuatan dapat dikategorikan menjadi; 1) Perbuatan yang tidak dalam posisi menempati keperluan umum (hajāt), maka diamnya Nabi bukanlah dalil adanya keharusan (wajib/ijāb), bukan pula dalil pengguguran bagi kebolehan suatu perbuatan bila pemberian penjelasan (al-bayān) betul-betul diakhirkan sampai dengan waktu yang dibutuhkan (ilā waqti al-hājah); 2) Perbuatan yang menempati keperluan umum, seperti kasus seorang Baduwi (A'rabī) yang bertanya mengenai menggauli isteri (jima') di bulan Ramadhan, kemudian ia diwajibkan memerdekakan budak sementara isterinya tidak. Diamnya Nabi menunjukkan bahwa memerdekakan budak juga wajib bagi si isteri karena mengakhirkan memberikan penjelasan (albayān) pada waktu yang dibutuhkan ('an waqti al-hājjah) itu tidak dibolehkan. ${ }^{29}$

\section{Tentang Khabar Mutawātir}

Al-Shīrāzī membahas mengenai akhbār (jamak dari khabar) sebagai ceritacerita yang disandarkan kepada Nabi. Menurutnya, khabar itu bisa benar atau salah dan dalam struktur bahasa ia mempunyai bentuknya sendiri. Sementara

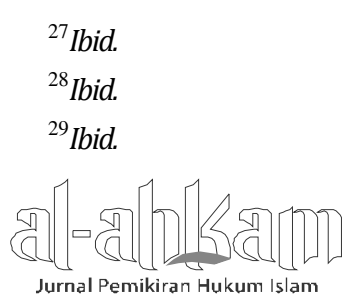


pendapat mazhab Asy'ariyah menafikannya. Kebenaran khabar mempunyai bentuk (sighat)-nya sendiri didukung oleh pembagian kalam yang dilakukan oleh ahli bahasa yang terdiri dari amar, nahi, khabar, dan istikhbar.30

Al-Shīrāzì membagi khabar ke dalam dua bagian, yaitu mutawātir dan ahād. Khabar mutawātir adalah khabar yang diketahui perawi/matannya secara darūrī. Khabar mutawātir terbagi menjadi dua, yaitu: mutawātir dari segi redaksi katakatanya, seperti khabar-khabar yang mempunyai kesamaan redaksi mengenai generasi-generasi (qurūn) masa lalu dan kota-kota/negeri-negeri (bilād) yang jatuh; dan mutawātir dari segi makna seperti khabar-khabar yang tidak sama redaksinya. Misalnya tentang kedermawanan Hātim dan keberanian Alī ibn Abī Tāàib dan khabar-khabar yang serupa dengannya. Al-Shīrāzī menegaskan bahwa terhadap kedua jenis khabar mutawātir tersebut, 'ilm (pengetahuan yang menimbulkan keyakinan) dapat dinisbahkan kepadanya.31 Menurut al-Shīrāzī syarat khabar mutawātir yang melahirkan 'ilmu ḍarūrī ada tiga: 1) penutur (mukhbir) mencapai jumlah yang tidak memungkinkan mereka bersepakat untuk berbohong; 2) awal dan pertengahannya sama; 3) khabar dalam permulaan penuturannya berasal dari penyaksian atau pendengaran. Adapun bila khabar itu berasal dari nazar dan ijtihād, maka pengetahuan yang dicapai tidak sampai bersifat darūrī. ${ }^{32}$

\section{Ijma'}

Menurut al-Shīrāzī, ijma' secara bahasa mengandung dua arti, yaitu: ijma' atas sesuatu serta berniat dan berketetapan hati atas sesuatu perkara. Adapun secara syara' berarti kesepakatan ulama masa tertentu mengenai hukum suatu kejadian. Ijma' merupakan satu di antara hujjah shar'iyyah dan satu di antara dalil-dalil hukum yang bersifat tetap dan mengikat bagi yang tidak menghadirinya pada saat ijma' dilakukan. ${ }^{33}$ Ijma' tidak akan terjadi kecuali didasarkan pada dalil, baik kita mengetahuinya atau tidak sama sekali. Dalil tersebut dapat berupa dalil akal, alQur'an, Sunnah, perbuatan dan ketetapan Nabi, qiyās, dan seluruh metode-metode ijtihād lainnya. ${ }^{34}$

\footnotetext{
${ }^{30}$ Ibid. h. 38.

${ }^{31}$ Ibid.

${ }^{32}$ Ibid.

${ }^{33}$ Ibid. h. 46.

${ }^{34}$ Ibid. h. 47.
} 
Ijma merupakan dalil bagi seluruh hukum-hukum syara' seperti ibadah, mu'amalat, pembunuhan, perkawinan, dan hukum-hukum lainnya seperti halalharam, fatwa-fatwa, dan hukum-hukum masalah-masalah tertentu. Adapun hukum-hukum akal (al-aḥkām al-aqliyyāt) terbagi menjadi dua: 1) wajib mendahulukan pengamalan dari pada mengetahui (al-ilm) seperti pengetahuan tentang barunya alam, penetapan Pencipta dan sifat-sifat-Nya, penetapan kenabian, dan yang semisalnya. Pada masalah-masalah ini tidak berlaku ijma' karena ijma' merupakan dalil dalil syara' yang ditetapkan berdasarkan pendengaran (al-sam'). Karena itu pula tidak dibolehkan menetapkan suatu hukum yang wajib diketahui sebelum mendengarkan (qabla 'l-sam'), sebagaimana tidak dibolehkannya menetapkan al-Kitab dengan al-Sunnah, sementara wajib mengamalkan al-Kitab sebelum al-Sunnah; 2) tidak wajib mendahulukan pengamalan atas mendengar (al-sam') seperti kebolehan melihat Allah dan kebolehan ampunan-Nya bagi para pendosa, dan hal-hal lain yang dibolehkan mengetahui sebelum mendengarkan (al-sam'). Pada perkara-perkara demikian ijma' dapat digunakan sebagai hujjah/dalil.35 Adapun terkait urusan duniawi seperti pengurusan tentara, pengaturan zona perang, kota, pertanian, dan perindustrian, ijma' tidak dapat dijadikan sebagai hujjah. ${ }^{36}$ Menurut al-Shīrāzī ijma' dapat diketahui dengan ucapan dan tindakan, ucapan dan penetapan, serta perbuatan dan penetapan. ${ }^{37}$

\section{Ontologi Qìyās, Istiḥsān, dan Istișhāōb}

Ketika membahas ontologi qiyās, al-Shīrāzī sama sekali tidak menyebut nama al-Syafi'i sebagai pencetus qiyās. Qiyās menurutnya adalah mempersamakan masalah cabang dengan masalah asal dalam sebagian hukum-hukumnya dikarenakan makna ('illat) yang ada pada keduanya. ${ }^{38}$ Kendatipun demikian, ada yang memaknai qiyās sebagai tanda bagi adanya hukum (al-amārāt 'ala 'l-ḥukm), juga ada yang memaknai sebagai perbuatan pelaku qiyās (fi'l 'l-qā'is), bahkan ada yang menyamakan qiyās berarti ijtihād. Al-Shīrāzī cenderung kepada pandangan yang pertama karena lebih bersifat iḍțirād/jāmi' dan in'ikās/māni' dalam arti bahwa ada

\footnotetext{
${ }^{35}$ Ibid.

${ }^{36}$ Ibid.

${ }^{37}$ Ibid.

${ }^{38}$ Teks aslinya sebagai berikut: حمل فرع على اصل فى بعض احكامه بمعنى يجمع بينهما ibid,, h. 51.$$
\square
$$

Jurnal Pemikiran Hukum Islam 
atau tiadanya qiyōs itu disebabkan karena ada atau tiadanya makna 'illat. Jadi makna 'illat itulah yang menunjukkan keabsahan qiyās. ${ }^{39}$ Ini sesuai dengan kaidah al-hukm yadūru ma'a 'illatih wujūdan wa'adaman.

Sementara pandangan yang kedua, yang menyatakan bahwa qiyās merupakan tanda bagi adanya hukum, tidaklah bersifat idțirād/jāmi'. Seluruh aspek yang terkait dengan usaha-usaha pencarian hukum dapat dimasukkan dalam definisi ini, misalnya: ḥaml al-muțlaq 'alā 'l-muqayyad, tartīb l-'amm 'alā 'l-khāṣ, dan lainnya. Akan tetapi aspek-aspek tersebut bukanlah qiyās. Karena itu tidak ada alasan yang dapat dibenarkan terhadap pendefinisian qiyās dengan ijtihād. ${ }^{40}$

Terkait dengan istịhsān, al-Shīrāzī mengutip Imām Abū Ḥanīfah bahwa istiḥsān adalah menghukumi sesuatu karena pertimbangan kebaikan tanpa dalil (al-hukm bimā yastahsinuh min ghayr dalīl). ${ }^{41}$ Namun Hanafiyah ada yang mendefinisikan dengan pengkhususan 'illat karena adanya makna (alasan) yang mewajibkan adanya pengkhususan itu (takhșiṣ al-illat bi ma'nan yujību al-takhṣiș), atau. pengkhushusan sebagian jumlah dari jumlah yang lebih besar karena adanya dalil yang mengkhususkannya (takhșiṣ ba'ḍ 'l-jumlah min 'l-jumlah bi dalīl yukhașșiṣuh). Akan tetapi bila yang dimaksudkan istiḥsān adalah takhṣiṣ ba'ḍ 'l-jumlah min 'ljumlah bi dalīl yukhașșișuh atau qawlun aw al-ḥukm bi aqwā 'd-dalīlayn, maka tidak ada seorangpun yang menentangya. 42

Menurut al-Shīrāzī, istiṣhāb al-ḥāl ada dua, yaitu: istiṣhāb ḥāl al-'aql dan istișhāb ḥāl al-ijmā'. istișhāb ḥāl al-'aql adalah kembali kepada kaidah bahwa pada dasarnya seseorang bebas dari tanggung jawab (al-rujū' ilā barā'ah al-dhimmah fi 'l-aṣl atau al-aṣl barā'ah al-dhimmah). Ini merupakan metode yang digunakan secara cepat oleh seorang mujtahid saat tidak ada dalil-dalil syara'. Seorang mujtahid tidak akan beranjak dari kaidah ini kecuali ada dalil syara' yang mengharuskan dari kaidah tersebut. Bila ditemukan satu di antara dalil-dalil syara', maka seorang mujtahid akan beranjak dari kaidah yang dimaksud, baik dalil tersebut berupa dalil manțūq (makna teks), mafhūm (makna di luar teks), naș, atau ẓahīr. Oleh karena itu, kondisi demikian akan terus dipegangi oleh seorang mujtahid karena ketiadaan dalil syara'. Apapun dalil syara' yang hadir, seorang mujtahid haram hukumnya

\footnotetext{
${ }^{39}$ Ibid., h. 51.

${ }^{40} \mathrm{Ibid}$.

${ }^{41}$ Ibid., h. 65.

${ }^{42}$ Ibid, h. 66.
} 
menggunakan istishhāb ḥāl setelah hadirnya dalil syara' tersebut.43 Terkait dengan kaidah: "Pengambilan/pemberlakuan pendapat yang lebih sedikit (al-qawlu bi aqall mā qīla)," al-Shīrāzī membahasnya dalam pasal tersendiri. ${ }^{44}$

Dalam pandangannya, sesuatu yang menafikan hukum itu sama seperti sesuatu yang menetapkan dari segi kewajiban pemenuhan dalil terhadapnya (alnāfi li 'l-ḥukmi fahuwa ka 'l-muthbit fi wujūb al-dalīl 'alayh). Al-Shīrāzī beralasan bahwa kepastian tentang penafian hukum tidak diketahui kecuali dari adanya dalil adalah sama seperti penentuan/kepastian penetapan hukum tidak diketahui kecuali dari adanya dalil. Bila penetapan hukum tidak diterima kecuali dengan dalil, maka penafian pun demikian. ${ }^{45}$ Ketika Al-Shīrāzī membahas mengenai urutan-urutan penggunaan dalil dan proses pengeluarannya, ia menyatkan bahwa bila seorang dihadapkan pada sebuah kasus, maka baginya wajib mencari jawaban secara hierarkhis dalam: 1) teks al-Qur'an dan makna zahirnya, makna tekstual (manțūq) dan makna di balik teks (mafhūm)-nya; 2) perbuatan dan penetapan Nabi Muhammad SAW; 3) ijma' ulama kota/daerah tertentu; 4) masalah pokok (aluṣūl) lalu meng-qiyās-kan masalah cabang (furū') terhadapnya. ${ }^{46}$

Al-Shīrāzī membahas mengenai ijtihād dan hal-hal yang terkait denganya. Ijtihad dalam tradisi fuqahä' adalah pengerahan segala kemampuan (tenaga dan pikiran) untuk mencari hukum syara'. Hukum syara' terbagi menjadi dua, yaitu hukum yang bersifat aqli dan hukum yang bersifat syar'i. Hukum 'aqli, seperti dalam permasalahan barunya alam, penetapan Sang Pencipta, penetapan kenabian, dan dasar-dasar agama yang lain, kebenarannya hanyalah bersifat tunggal. Artinya, bila yang satu benar, maka yang lain salah/batal. ${ }^{47}$ Sedangkan hukum syara' yang bersifat syar'i terbagi menjadi dua bagian, yaitu: yang dibolehkan ijtihād dan yang tidak dibolehkan. Hukum yang tidak dibolehkan ijtihād dibagi lagi menjadi dua: 1) Apa yang diketahui melalui agama Rasulullah SAW secara aksiomatis (ḍarūrī), seperti: shalat, zakat, pengharaman riba, sodomi, minum khamar, dan lainnya. Barang siapa mengingkarinya setelah mengetahuinya, maka ia tergolong kafir serta mendustakan informasi dari Allah dan Rasul-Nya. Karena permasalahan itu telah diketahui dari agama Rasulullah SAW secara aksiomatis

\footnotetext{
${ }^{43}$ Ibid., h. 66-67.

${ }^{44}$ Ibid., h. 67.

${ }^{45}$ Ibid.

${ }^{46}$ Ibid. h. 67-68.

${ }^{47}$ Ibid.$$
\text { 口 }
$$

Jurnal Pemikiran Hukum Islam
} 
(ḍarūrī); 2) Apa yang tidak diketahui dari Agama Rasulullah SAW secara aksiomatis (darūrī), seperti hukum-hukum yang ditetapkan berdasarkan kesepakatan sahabat dan ahli hukum kawasan tertentu. Kebenarannya hanyalah satu, yaitu apa yang telah disepakati oleh sahabat atau fuqahä'. Barang siapa mengingkarinya setelah mengetahuinya, maka ia tergolong fasiq. ${ }^{48}$ Adapun hukum syara' yang bersifat syar'i yang dibolehkan ijtihād adalah seluruh masalah yang menjadi fokus perbedaan pendapat di kalangan ahli hukum kawasan tertentu. ${ }^{49}$

Menanggapi perbedaan pandangan tentang kebenaran ijtihād, Al-Shīrāzī menilai bahwa kebenaran hanya pada seorang mujtahid sementara mujtahid yang lain salah dan dosa akibat dari kesalahan ijtihād dihapus dari si mujtahid yang salah. Pilihan al-Shīrāzī di dasarkan pada sabda Nabi: إذا اجتهد الحاكم فاصاب فله أجران و إن إنجان Seandainya semua mujtahid benar tentu tidak diperlukan pengkajian dan pembahasan secara bersamaan ketika memilih fatwa-fatwa mereka. Adapun dalil mengenai dihapus dosa akibat kesalahan ijtihād, di samping didasarkan pada sabda Nabi di atas, juga didasarkan pada peristiwa bahwa para sahabat telah bersepakat atas pengabsahan penetapan hukum yang didasarkan pada pendapat dan penetapan (iqrār) dari setiap mujtahid/mufti yang berbedabeda dalam sebuah kasus tertentu. Kondisi demikian, menunjukkan bahwa tidak ada dosa bagi setiap mujtahid yang salah dalam berijtihad. ${ }^{50}$

\section{Karakteristik Kitab al-Luma'}

Memahami karakteristik kitab al-Luma ${ }^{51}$ harus dimulai dari penjelasan ketiga fase terkait dengan penulisan karya-karya di bidang ușūl al-fiqh yaitu: fase awal, fase perkembangan, dan fase kesempurnaan. Hal ini karena ketiga fase tersebut mempunyai karakteristik yang berbeda antara satu dengan yang lain.

\footnotetext{
${ }^{48}$ Ibid., h. 70-71.

${ }^{49}$ Ibid. h. 71.

${ }^{50}$ Ibid.

${ }^{51}$ Kitab al-Luma' di nilai Hassan Hanafi sebagai kitab ușūl al-fiqh yang memuat materi atau pendapat mengenai ragam pemikiran usūl al-fiqh dengan memakai konstruksi ilmu pengetahuan yang bersisi empat yaitu: al-Ahkām al-Shariyyyah, al-Adillah al-Shar'iyyah, turūq al-istidläl; dan ketentuan-ketentuan ijtihād, taqlid, dialektika kontradiktif, dan tarjih. Materi-materi ini kemudian di transformasikan ke dalam bab-bab, pasal-pasal, kelas-kelas, dan tulisan, yakni tujuh bab dalam Irshād al-Fukhūl karya al-Shaukanī, dua belas bab dalam al-Mankhul karya al-Ghazālī, dan lainnya. selengkapnya lihat Hassan Hanafi, Islamologi I; Dari Teologi Statis ke Anarkis, terj. Miftah Faqih, Cet. II (Yogyakarta: LKiS, 2007), h. 107.
} 
Fase awal bertepatan dengan abad ke-3 H. saat Dinasti Abbasiyah berkuasa. Pada masa ini gerakan ilmiah terjadi di dunia Islam. Pada masa ini pula pemikiran ușūl al-fiqh telah ditulis dalam bentuk karya intelektual di antaranya adalah alRisālah karya Imam al-Syafi'i (w. 204 H.); Kitab Ithbāt al-Qiyās, Khabar al-Wāhid, Ijtihād al-Ra'y karya Ibn Șadaqah al-Ḥanafī, Isā ibn Ibān (w. 221 H.); Kitāb al-Nukāt karya Ibrāhim ibn Sayyār ibn Hānik yang dijuluki al-Naḍ̣ām (w. 221 H.). Di dalam kitab ini an-Naḍḍ̄m menafikan kehujjahan ijma'. Ia juga termasuk salah seorang di antara yang paling brilian dalam mazhab Mu'tazilah. Ia belajar ilmu kalam dari Abū Hudhayl al-'Allāf, banyak mempunyai pemikiran bebas dan mandiri; ${ }^{52}$ Kitab fi Ușūl al-Fiqh Imām Dār al-Hijrah karya Aṣbāgh ibn al-Farrāj ibn Sa'īd ibn Nāfi' al-Miṣrī (w. 225 H.); Kitab al-Ijmā', Kitāb Ibțāl al-Taqlīd, Kitāb Ibțāl al-Qiyās, Kitāb Khabar alWāhid, Kitāb al-Khabar al-Mujīb li 'l-'Ilmi, Kitāb al-Hujjah, Kitāb al-Khușūs wa 'l'Umūm, Kitāb al-Mufassar wa I-Mujmal, karya Dāwud ibn 'Alī ibn Dāwud al-Ẓāhirī (w. 270 H.). Kecuali al-Risālah, secara umum karya-karya uṣūl al-fiqh fase pertama ditulis bersama sama dengan fikih. Inilah barangkali yang mengundang klaim ahliahli hukum mazhab menisbatkan karya-karya ușūl al-fiqh awal pada imamimamnya masing-masing, seperti yang dilakukan oleh penganut mazhab Imam Malik ibn Anas. Ușūl al-fiqh pada masa ini di arahkan pada usaha perintisan awal yang bersifat bebas dan penyempurnaan.

Fase awal ini terjadi inventarisasi ahli-ahli hukum ternama yang meletakkan dasar-dasar mazhab-mazhab hukumnya atau murid-murid mereka yang mengetengahkan dasar-dasar ijtihād (ușūliyyah ijtihādiyyah)-nya, mengambil perbedaan yang ada di kalangan mereka, mengkritik lalu menulisnya. Pengikut Imam al-Syafi'i misalnya, tidak diketahui mengambil metode istihsān yang banyak dilakukan oleh para pengikut imam Hanafì yang umumnya tidak mendasarkan hukum-hukum yang diambil dengan ragam hadis (kecuali hadis mutawātir) sebagaimana yang banyak dilakukan oleh pengikut imam al-Syafi'i. Berbeda dengan mereka (pengikut Ḥanafi dan al-Syafi'i), ahli hadis secara umum dan pengikut Zāhiriyyah secara khusus, tidak mendukung sikap dan pilihan yang diambil oleh kedua pengikut tersebut. Bahkan mereka menentang keberadaan qiyās. Mereka lebih memilih berijtihad dengan menta'wilkan al-Qur'an dan al-Hadis, demikian juga segolongan ahli kalam dari Mu'tazilah. Masing-masing pengikut membentengi dasar-dasar

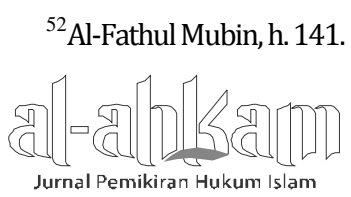

Volume 22, Nomor 2, Oktober 2012 
pengambilan hukum (ușūl al-fiqh) mazhabnya dari serangan lawan, mengkritik dan mengklaim salah dasar-dasar pengambilan hukum yang dimiliki mazhab lain.53

Fase perkembangan terjadi pada abad ke-4 H. Pada fase ini gerakan ilmiah secara umum mengalami perkembangan dan secara khusus ilmu uṣūl al-fiqh juga mengalami hal yang sama. Pada fase ini Dinasti Abbasiyah yang berpusat di Baghdad secara politik telah melemah. Posisi khalifah hanya sekedar simbol. Kekuasaan kekhalifahan Abbasiyah terbagi menjadi kerajaan-kerajaan kecil. Hanya saja, melemahnya kekuatan politik ini tidak mempengaruhi semangat gerakan ilmiah yang ada pada setiap orang di seluruh daerah kekuasaan Islam. Setiap Muslim dapat melakukan rihlah 'ilmiyyah di setiap negara bagian Islam secara bebas. Bila buah politik telah jatuh pada abad ke-4 H, maka justeru sebaliknya buah gerakan ilmiah telah matang di abad ini. ${ }^{54}$

Ilmu ușūl al-fiqh pada masa ini mengalami perkembangan cukup signifikan, dimana kajian dan penelitiannya sangat luas. Karena seluruh kegiatan ulama ușūl al-fiqh dicurahkan pada bidang ilmu ini. Usaha keras tersebut memberikan dampak besar bagi pencapaian perkembangan ilmiah terhadap terminologi ilmu uṣūl al-fiqh dari segi makna dan objeknya. Beberapa karya ușūl al-fiqh yang di hasilkan pada masa ini, di antaranya adalah al-Dhākirah fi Ușūl al-Fiqh karya Abū Bakar Aḥmad ibn al-Ḥusayn ibn Sahl yang dikenal dengan Ibn Burhān al-Fārisī (w. 305 H); Kitāb al-Radd 'alā Ibni Dāwūd fi Ibțāl al-Qiyās, Risālah al-Bayān 'an Ușūl alAhkām karya Abū al-'Abbās Aḥmad ibn 'Umar ibn Surayj (w. 306 H.); Kitāb al-Ijmā' karya Abū Bakar Muhammad ibn Ibrāhīm ibn al-Mundhīr an-Naysabūrī (w. 318 H.); Ithbāt al-Qiyās, Kitāb al-Khāșs wa 'l-'Ām karya 'Alī ibn Ismā'îl ibn Abū Bashar yang ber-kunyah Abū al-Ḥasan al-Ash'arī (w. 324 H.); Kitāb al-Bayān fi Dalā'il al'A'lām 'alā Ușūl al-Ahkām, Kitāb al-Ijmā', Sharah Risālah al-Imām al-Shāfíi karya Muhammad ibn 'Abdullāh yang ber-kunyah Abū Bakar dan terkenal dengan sebutan al-Șayrafì (w. 330 H); Kitāb al-Luma' karya al-Qāḍī Abū al-Farrāj 'Amr ibn Muhammad ibn 'Amr al-Laythī al-Mālikī (w. 331 H.); Kitāb al-Jidāl fí Ușūl al-Fiqh karya Abū Manșūr al-Matūridī al-Ḥanafî Muhammad ibn Muhammad ibn Mạ̣mud (w. 333 H.); Muṣannaffi Ușūl al-Fiqh karya Aḥmad ibn Aḥmad Abū al-'Abbās al-Qāṣ (w. 335 H.); Ușūl al Karkhī karya Ubaydillāh ibn Dallāl ibn Dalhạm yang ber-kunyah

\footnotetext{
${ }^{53}$ Ibid., h. 103.

${ }^{54}$ Ibid. h. 105.
} 
dengan Abū al-Ḥasan al-Karkhī (w. 340 H.); Kitāb al-Ușūl karya Abū Bakar Muhammad ibn Ismā'īl al-Siyāsī al-Qaffāl al-Kabīr (w. 365 H.); dan kitab-kitab ushul yang lain. 55

Pada masa ini, sebagian ulama ușūl al-fiqh mempunyai perhatian besar terhadap Kitāb al-Risālah karya Imam al-Syafi'i. Di antara yang melakukan kajian dan komentar terhadap karya al-Syafi'i tersebut adalah Abū Bakar Muhammad ibn 'Abdullāh al-Ṣayrafi, (dalam Kitab Dalāil 'A'lām), Abū al Walīd Hissān ibn Muhammad an-Naysabūrī al-Qurashī al-Umawī (w. 349 H.), dan al-Imām Muḥammad ibn Ismā’̄l 'Ali al-Qaffāl al-Kabīr al-Siyāsī. Fakta-fakta ini menunjukkan bahwa al-Risālah karya al-Syafi'i mempunyai posisi penting di mata pakar uṣūl al-fiqh pada masa ini sehingga menarik perhatian mereka untuk melakukan penulisan dan pengkajian. ${ }^{56}$

Fase perkembangan ini juga telah melahirkan kajian-kajian dan penulisan teori-teori ushul mazhab Hanafì baik terhadap pemikiran maupun metodenya yang bereda dengan mazhab lain. Ușūl al-fiqh ala mazhab Hanafi ini mencapai kesempurnaan ditangan Abū Bakar al-Rāzī dalam Kitab al-Fușūl fi l-Ușūl. Dengan pencapaian tersebut, ahli-ahli ushul mazhab Hanafi mengetengahkan perbedaan pandangannya dengan pandangan dari ahli-ahli ushul mazhab Mutakallimin. Sebagaimana dalam kelompok Mutakallimin terdapat ahli ushul yang mampu menciptakan inovasi baik dalam pemikiran maupun tulisan dalam menghadirkan masalah ushuliyah baru, maka demikian pula dalam kelompok mazhab Hanafi.57

Fase kesempurnaan terjadi pada abad ke-5 H sampai dengan pertengahan abad ke-7 H. Gerakan ilmiah pada masa ini merupakan kelanjutan secara alamiah dari perkembangan pengetahuan dan gerakan peradaban pada abad ke-4 $\mathrm{H}$. Bahkan sebagian sejarawan ilmu pengetahuan dan sastra memasukkan periode yang terjadi di awal abad ke-4 H sampai dengan abad ke-7 H menjadi fase sejarah yang satu dan bercorak sama dalam hal kegiatan dan persaingan ilmiah yang terjadi pada beberapa kekuasaan politik yang berbeda. Periode ini melahirkan beberapa pusat ilmu pengetahuan, seperti: Isfahān, Rayy, Istana Raja Sultan Maḥmūd al-Ghaznāwī di Ghaznah, Istana Raja Saljuk di Marw dekat Khurasan, Istana Raja Țulūniyyah, Iḥshidiyyah, Fāțimiyyah di Mesir, dan lainnya. Ibu kota-ibu kota

\footnotetext{
${ }^{55}$ Ibid, h. 110-116.

${ }^{56}$ Ibid., h. 119.

${ }^{57}$ Ibid.

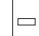

Jurnal Pemikiran Hukum Islam
} 
Islam, seperti Cordova, Baghdad, Kairo, Bukhara, Ghaznah, Isfahan, dan lainnya bersaing secara ketat. Pada masa ini pula Andalusia menjadi pusat peradaban Islam yang maju dalam ilmu pengetahuan, arsitektur, dan bidang lainnya. ${ }^{58}$

Karya-karya ușūl al-fiqh yang ditulis pada fase ini antara lain: al-Taqrīb min Ușūl al-Fiqh, al-Muqnī’ fi Ușūl al-Fiqh, Amalī Ijmā' Ahl al-Madīnah karya al-Qāḍī Abū Bakar Muhammad ibn Țayyib ibn Ja'far ibn al-Qāsim yang di kenal dengan alBāqillanī al-Bașrī al-Mālikī (w. 403 H); Kitāb Ușūl al-Fiqh karya al-Ḥasan ibn Ḥāmid ibn 'Ali ibn Marwan Abū 'Abdullah al-Baghdādī (w. 403 H); Kitāb Ușūl al-Fiqh karya Aḥmad ibn Muhammad ibn Aḥmad al-'Isfirayanī Abū Hāmid (w. 406 H); Kitāb Ușūl al-Fiqh karya Muhammad ibn Muḥammad ibn Nu'mān 'Abdussalām, Abū 'Abdullāh yang terkenal dengan sebutan al-Shaykh al-Mufïd ibn al-Mu'allim (w. $413 \mathrm{H}$ ); alIṇkām fi Ușūl al-Ahkām, Masāíl min al-Ușūl karya 'Alī ibn Aḥmad ibn Sẫd ibn Hazm bi Ghālib ibn Ṣāliḥ al-Umawī Abū Muḥammad ibn Hazm (w. 456 H); Kitāb al-Luma' fi Ușūl al-Fiqh wa Sharhih, al-Tabṣirah fi Ușūl al-Fiqh karya Abū Ishāa Ibrāhīm ibn 'Alī ibn Yūsuf al-Shīrāzī al-Fayrūz Abādī (w. 476 H), dan lainnya.59

Fase ini melahirkan banyak tokoh ușūl al-fiqh brilian dan mujtahid kenamaan. Mereka banyak mencurahkan tenaga dan pikirannya untuk menulis dan mengembangkan ilmu uṣūl al-fiqh. Mereka mewariskan kepada generasi sezaman pemikiran orisinal yang bebas dan merdeka. Perbedaan pada sebagian topik-topik penting seperti kehujjahan qiyās, istiḥsān, hadis aḥād, hadis mursal, qawl al-ṣaḥabì, merupakan sebab gesekan pemikran dan tindakan nyata perbuatan dalam melakukan gerakan kritik yang merupakan urat nadi dari kebebasan pemikiran dalam ilmu ușūl al-fiqh.60

Periode ini melahirkan corak ușūl al-fiqh baru yang tidak sama dengan periode sebelumnya. Karya-karya inti dalam bidang ușūl al-fiqh perbandingan (muqāran) muncul ketika diketengahkan ragam pemikiran mazhab, pencarian dalil (istidlāl) dan pentarjihan bagi dan di antara ragam pemikiran tersebut. Model seperti ini dapat dilihat baik dalam karya-karya para pakar ușūl al-fiqh mazhab Mutakallimin maupun Aḥnāf. Karenanya, karya-karya ușūl al-fiqh yang secara khusus mengkaji tentang perbedaan isu-isu atau ketentuan yang bersifat dasar (ușūliyah) semakin

\footnotetext{
${ }^{58}$ Ibid. h. $165-167$.

${ }^{59}$ Ibid. h. 170-181.

${ }^{60}$ Ibid. h. 443.
} 
marak. Karya seperti ini dapat dilihat, misalnya, pada Kitāb al-Tabșirah fi Ușūl alFiqh karya Abū Ishāạ Ibrāhīm al-Shīrāzī al-Fayrūz Abādī, dan karyanya yang lain.61

Para pengikut mazhab-mazhab fikih seperti Hanafi, Maliki, Syafi'i, Hanbali, Zāhiri, dan lainnya melalui tokohnya masing-masing menulis kitab uṣūl al-fiqh. Sehingga setiap mazhab fikih mempunyai kitab uṣūl al-fiqh sendiri yang mengacu pada ușūl al-fiqh imam mazhabnya, yang memperkuat pendapat dan pandangan pemikiran mereka (imam mazhab), mengacu pada sumber-sumber pengambilan hukum dan metode ijtihadnya dalam setiap masalah dan keputusan yang bersifat dasar (ușūliyyah). ${ }^{62}$

Fase ini juga telah lahir arah pemikiran baru, yaitu penyajian permasalahan dasar (ușūliah) dan isu-isunya yang bernuansa kalam dari segi pandangan ulama salaf. Contohnya adalah dalam karya para pakar ușūl al-fiqh pengikut Imām Aḥmad ibn Hanbal (Hanābilah) sebagaimana dapat dilihat pada pandangan al-Qāḍi Abū Ya'lā. Karena itu, dalam ușūl al-fiqh muncul empat kecenderungan arah pemikiran, yaitu; mu'tazilī, ash'arī, salafi, dan matūridī. Muatan topik/objek kajiannya juga beragam, ada yang bersifat lughawī (kebahasaan), jadalī (perdebatan/bantahan), kalamī, manțiqī, dan falsafi. 63

Para pakar uṣūl al-fiqh pada fase ini telah melahirkan karya uṣūl al-fiqh terbaik sebagai produk ilmiah baik secara umum maupun khusus yang di dalam sejarah ilmu uṣūl al-fiqh disebut sebagai masa keemasan. Melalui produk ilmiah ini jelas sekali metode para pakar ușūl al-fiqh dalam meletakkan ilmu uṣūl al-fiqh, membangun kaidah-kaidahnya, dan penyusunannya. Kedua metode tersebut merupakan metode yang berdiri sendiri, yaitu metode Mutakallimin dengan segenap perbedaan mazhab fikih yang ada di dalamnya dan metode Ahnāf. Keduanya mempunyai keistimewaan, metode, serta topik-topiknya masing-masing. ${ }^{64}$

\section{Kesimpulan}

Pertama, Pemikiran uṣūl al-fiqh Abū Ishāa Ibrāhīm al-Shīrāzī yang termuat dalam Kitab al-Luma' ditulis pada fase kesempurnaan, era keemasan karya-karya uṣūl al-fiqh, sehingga metode dan pokok-pokok pemikiran uṣūl al-fiqh-nya banyak

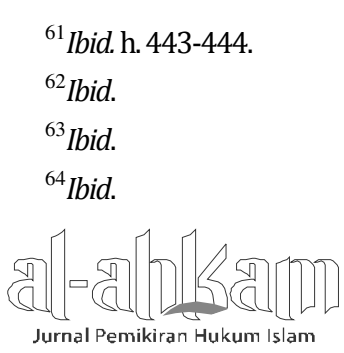


diikuti dan menjadi sumber inspirasi bagi generasi berikutnya. Pengungkapan content uṣūl al-fiqh didasarkan pada metode tokoh-tokoh ușūl al-fiqh sebelumnya. Hal ini tampak jelas dalam metode komparatif yang digunakan oleh al-Shīrāzī ketika mengetengahkan materi-materi ușūl al-fiqh dari beberapa tokoh uṣūl al-fiqh yang berbeda pandangan. Kedua, al-Shīrāzī tergolong ahli ushul Mutakallimin yang mempunyai pemikiran orisinal dan merdeka. Kebebasan berpikirnya cenderung bergesekan dengan tokoh lain, di mana beliau sering mengkritik tokoh-tokoh lain yang berbeda pandangan. Kritik-kritik yang dilakukan lebih diarahkan pada topiktopik sentral dari pada perdebatan-berdebatan yang bersifat individual, tanpa adanya kecenderungan terhadap madzab fikih tertentu. Model penyajian pemikiran ușūl al-fiqh al-Shīrāzī yang termuat dalam al-Luma' lebih bersifat kalamī, karena argumentasi yang dibangun melibatkan unsur-unsur kalam dan mengedepankan logika menjadi alat dalam menilai dan mengukur kebenaran ilmu ușūl al-fiqh. Ketiga, al-Luma' telah memenuhi dasar-dasar ilmu pengetahuan baik secara ontologi, epistemologi, maupun aksiologi.[a]

\section{DAFTAR PUSTAKA}

al-Shīrāzī al-Fayrūz Abādī, Abū Ishāq Ibrāhīm, al-Muhadhdhab fi Fiqh al-Imām alShāfi'î, juz I, cet. I, Beirut-Lebanon: Dār al-Kutub al-'Ilmiyyah, 1995.

al-Shīrāzī al-Fayrūz Abādī, al-Luma', Penerbit Karya Thoha Putra, Semarang, tth.

Hanafi, Hassan, Islamologi I; Dari Teologi Statis ke Anarkis, terj. Miftah Faqih, cet. II, Yogyakarta: LKiS, 2007.

Ibrāhīm ibn Sulaymān, 'Abdul Wahhāb, Al-Fikr al-Uṣūlī: Dirāsah Taḥhlīiliyyah Naqdiyyah, t.t.p.: t.p., t.th.

Isma'īl al-'Āmirī aș-Șan'anī, Muhammad,; Muhammad Subḥi Ḥasan Ḥallaq (ed.)., Subūl al-Salām, Cet. II, Jilid IV, Riyaḍ: Dār Ibn al-Jawzy, 1421 H.

Khallikan, Ibn, Wafāyāt al-A'yān wa Anba'u Abnā'i az-Zamān, Dr.Ihsan Abbas, ed., Jilid I, Beirut-Lebanon: Dār 'alā 'th-Thaqāfah, 1970.

Maḥfūz, Muḥammad Aḥmad Sahal, al-Bayān al-Luma' 'an Alfāz al-Luma', Semarang: Toha Putera, t.th.

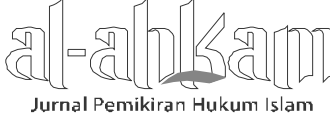

